\title{
Garapen Iraunkorrerako Helburuei so hizkuntzen betaurrekoekin
}

\author{
(Filling the gap in the Sustainable Development Goals \\ from the language perspective)
}

\author{
Ines M. ${ }^{a}$ Garcia-Azkoaga*, Itziar Idiazabal \\ UPV/EHUko Munduko Hizkuntza Ondarearen UNESCO Katedra (UPV/EHU)
}

LABURPENA: Lan honen helburua 2030 Agendako Garapen Iraunkorrerako Helburuen (GIH) eta hizkuntza-aniztasunaren arteko loturaz gogoeta egitea da. Hizkuntzak Nazio Batuen Erakundeak zehaztu dituen 17 helburuak besarkatzen ditu halabeharrez, baina 2030 Agendan ez da formulazio espliziturik egiten horri buruz. Hutsune hori agerian jartzeko, «17+1» aldarrikapena egin da, hizkuntzen helburuari buruzko (18. helburua) argudioak erakutsiz. Hizkuntza-aniztasunaren eta eleaniztasunaren gogoeta erdigunera ekarri, eta, garapen iraunkorrerako 4. helburua (hezkuntza) adibidetzat hartuta, hizkuntzak garapenaren eragile moduan duen garrantzia aztertu da artikulu honetan. 18. helbururako zerrendatxo bat ere eskaini da, «17+1» deritzon aldarrikapena nabarmentzeko. Ondorio zenbait ere atera dira, eta haien artean garrantzizkoena da hizkuntza bere horretan helburu guztietan agertu beharko litzatekeela jomuga moduan, hura delako helburu horiek erdiesteko dagoen tresna bazterrezina eta garrantzizkoena.

HITZ GAKOAK: hizkuntza-aniztasuna, garapen iraunkorra, ama-hizkuntza, hizkuntza gutxituak, hizkuntza-ondarea, hizkuntzak eta garapena, «17+1».

\begin{abstract}
The aim of this article is to reflect on the connexion between the 2030 Agenda's Sustainable Development Goals (SDG) and language diversity. Languages are tightly connected to the 17 goals proposed by the United Nations, but there is no explicit mention of them in the agenda. In order to give visibility to languages and the need to consider them for sustainable development, $a$ «17+1» proclamation is made and arguments are made about the purpose of languages (goal 18). Based on the reflection on linguistic diversity and multilingualism, and taking as an example the $4^{\text {th }}$ goal of sustainable development (education), the importance of language as an agent of development is studied. A short list of meta-objectives for the $18^{\text {th }} S D G$ is provided to highlight the so-called «17+1» claim. Some conclusions are also drawn the most important one being that language should appear as a goal as it is the most indispensable and important tool for achieving these goals.
\end{abstract}

KEYWORDS: language diversity, sustainable development, mother tongue, minorized languages, language heritage, languages and development, «17+1».

\footnotetext{
* Harremanetan jartzeko / Corresponding author: Ines M. ${ }^{a}$ Garcia-Azkoaga, UPV/EHUko Munduko Hizkuntza Ondarearen UNESCO Katedra (UPV/EHU), Micaela Portilla Ikergunea, Justo Vélez de Elorriaga, 1 (01006 Vitoria-Gasteiz, Araba). - ines. garciaazkoaga@ehu.eus - https://orcid.org/0000-0003-1235-2583.

Nola aipatu / How to cite: Garcia-Azkoaga, Ines M.;. Idiazabal, Itziar (2021). "Garapen Iraunkorrerako Helburuei so hizkuntzen betaurrekoekin»; Ekaia, ale berezia 2021, 277-296. (https://doi.org/10.1387/ekaia.22087).

Jasotze-data: 2020, urriak 01; Onartze-data: 2021, urriak 18
}

ISSN 0214-9001 - elSSN 2444-3255 / (c) 2021 UPV/EHU

(c) (i) $(-)$ Lan hau Creative Commons Aitortu-EzKomertziala-LanEratorririkGabe 4.0 Nazioartekoa

(c) ${ }_{\mathrm{BY}} \mathrm{NC}$ No lizentzia baten mende dago 


\section{SARRERA}

Euskal Herrian bezala, hainbat hizkuntza-komunitate, alorreko aditu eta erakunde arduradunek aski frogatua dute tokian tokiko hizkuntza gutxituaren biziberritzea garapenerako indarra dela $[1,2]$.

UNESCO Bangkok [3] izenez ezagutzen den txostenak oso argi eta argudio indartsuekin erakusten du nolako garrantzia duen hizkuntzak tokian tokiko hizkuntzaren edo norberaren hizkuntzaren bizi-indarraren eta gizataldeen garapenean. Txosten horretan, Nazio Batuen Milurtekoko Deklarazioan [4] ageri ziren helburu nagusien harira, hizkuntza gutxituen bermeak nolako eragina duen erakusten da: pobreziaren, gosearen eta bazterkeriaren kontra egiteko, Lehen Hezkuntzaren kalitatearen berme gisa, nesken eta emakumeen eskubideen alde egiteko, oinarrizko osasun-baldintzak erdiesteko... [5]. Horiek guztiak ondo jasotzen ditu txosten horrek, eta hona ekarriko ditugu aipu batzuk:

Konbentzimendu osoa dugu hizkuntza kontuan hartzea Milurtekoko Garapen Helburuak lortzeko ezinbesteko baldintza dela. [...] Izan ere, hizkuntza integrazioaren giltzarria da, gizakiaren jardueraren gunea, norberaren adierazpide eta identitatea. Jendeak hizkuntza propioari ematen dion lehentasunezko lekua aitortuz, hizkuntza propioa erabiliz, garapenean benetako parte-hartzea sustatu nahi da, interbentzioaren emaitzak iraunkorrak izan daitezen. [5]

Milurtekoko Deklarazioan, hizkuntzen garrantzia, ordea, ez zen kontuan hartu, eta aipatutako Bangkok Txostenak salaketa garbia egiten du:

Hizkuntzak, oro har, ez dira txirotasuna murrizteko nazioarteko dokumentu eta plangintzetan agertzen esplizituki oraindik. Beraz, horrek adierazten du gutxiengo etniko eta linguistikoei arreta ez-nahikoa eskaintzen zaiela, bereziki haien garapen-prozesuei dagokienez. [5]

Hezkuntzaren alorrean, oso ezaguna da norberaren hizkuntza garatzeak duen garrantzia, eta hori ere argi ageri da txosten horretan:

Hizkuntza propioa kontuan ez hartzeak gutxiengo etnolinguistikoko haurrei bazterketa eta diskriminazioa betikotzea ekartzen die. [...] Beren hizkuntzan oinarritutako heziketak, aldiz, haurrei laguntzen die; esate baterako, autokonfiantza hobetzen. Horrela hobeto ikasten dute, baita beste hizkuntzak ere. Gainera, bestelako eskola-gaietan ere egokiago moldatzeko aukera izaten dute, eskola-porrota gutxitzeko eta familia-giroan babesa eta laguntza izateko. [5] 
Nesken eta emakumeen eskubideei dagokienez ere, eta bereziki haien osasunarekin lotuta, oso eraginkorra da norberaren hizkuntza kontuan hartzea, eta hala jasotzen da txostenean:

Bizitza asko salba daitezke baldin eta emakumeek informazio egokia jasotzen badute, adibidez, elikaduraz edota edoskitzeaz, edota osasunarloan beherakoa, malaria eta beste gaitz batzuk ekiditeko moduaz. Horregatik, emakumeek beren hizkuntzan eta testuinguru kulturala kontuan hartuta jaso behar dute informazioa, eraginkorra izateko. [5]

Gaur, Nazio Batuen 2030 Agendaren [6] Garapen Iraunkorrerako Helburuen $(\mathrm{GIH})$ inguruan berriz ere gogoeta eta salaketa egin beharrean gara. 17 helburu proposatzen dira gizartean nahiko ezagun diren hainbat alorretan. GIH ekimena esanguratsua eta eraginkorra izan dadin, zabalkunde eta konpromiso-sare indartsua garatzen ari da munduko erakunde guztietan, eta ahalegin handia egiten ari dira maila guztietako erakundeen ardura ez ezik norbanako ororena izatera ere irits daitezen.

Agendaren sarreran garbi adierazten da Milurtekoko Helburuak erreferentzia harturik egiten dela proposamen berria:

Milurtekoko Garapen Helburuei ekin nahi zaie berriro, eta horiek lortu ez zutena lortu nahi da. [...] Agenda berria Milurtekoko Garapen Helburuetan oinarritzen da eta horien bidez lortu ez zena lortzea du xede, bereziki ahulenengana heltzeko. [6]

Baina 17 helburuen eta haien garapenerako formulatzen diren 169 erronken artean ez dugu ia-ia aurkitzen norbanakoen eta talde etnolinguistikoen ezaugarri kultural eta linguistikoen aldeko bermerik. Hauxe da nolabait horrekin lot litekeen aipamen bakarrenetakoa: «Jatorri etnikoa eta kultura-aniztasuna errespetatzen dituen mundua nahi dugu» [6].

Hizkuntzak ez dira inon ageri (1. irudia). Horrenbestez, eta hizkuntzak helburu horiek guztiak zeharkatzen dituela kontuan harturik, 2030 Agendan ezartzen diren helburuak hankamotz geratzen dira, funtsezko zutaberik gabe.

Helburuak erdiesteko orduan, ezin da alde batera utzi munduko hizkuntza-aniztasuna (2. irudia). Pentsa dezagun, bestela: pandemia-egoera batean, esate baterako, zer hizkuntzatan jaso behar lituzke pertsona batek gaixotasunetik babesteko jarraibideak, eta zer hizkuntzatan jaso behar luke giza komunitate batek gaixotasunari aurre egiteko ezagutza zientifikoa? (3. helburua: guztiontzat eta adin guztietan bizimodu osasungarria bermatzea eta ongizatea sustatzea); nola lortuko dugu kalitatezko hezkuntza (4. helburua: guztiontzako kalitatezko hezkuntza inklusiboa nahiz bidezkoa bermatzea eta etengabeko ikaskuntzarako aukerak bultzatzea) komunitate 


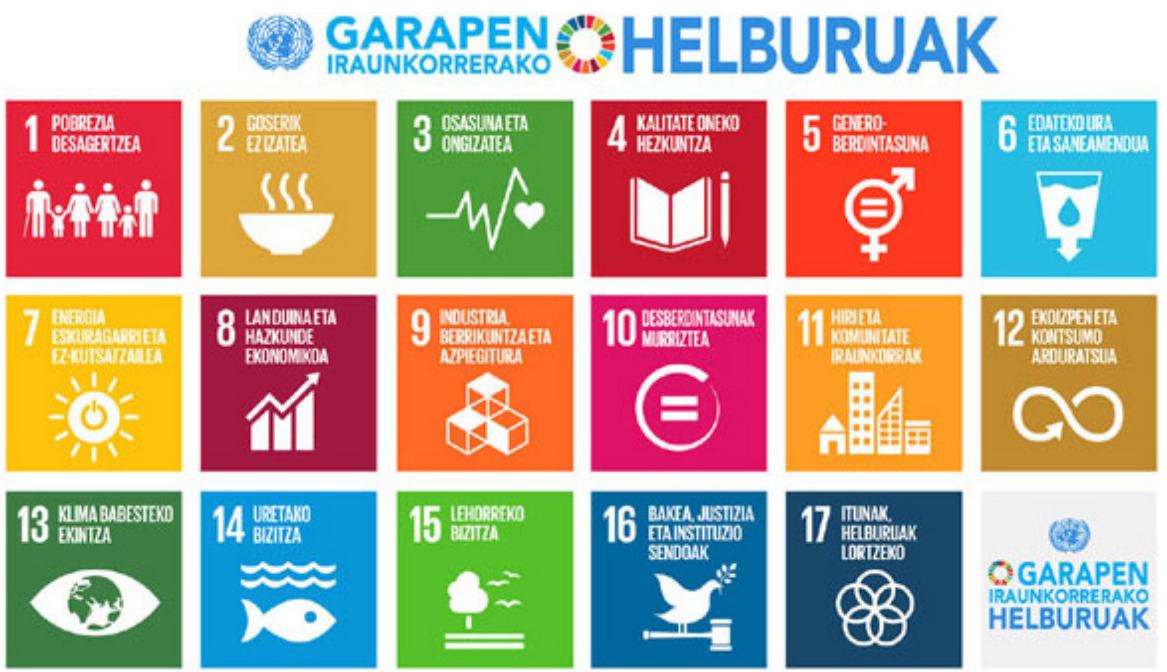

1. irudia. Garapen iraunkorrerako 17 helburuak (Nazio Batuen 2030 Agenda).

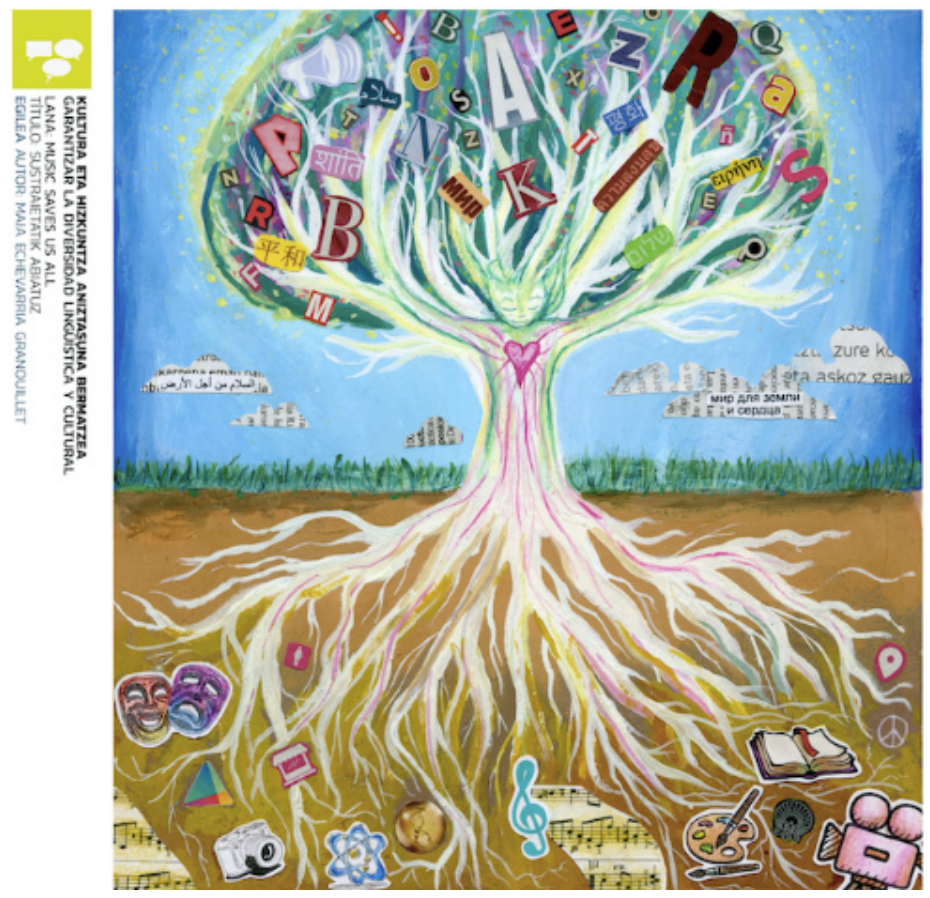

2. irudia. Hizkuntza- eta kultura-aniztasunaren irudikapena (EASO Politeknikoa). 
indigenetako hiztunek ez badute eskubiderik beren hizkuntzetan alfabetatuak eta eskolatuak izateko?; helburua enplegagarritasuna eta lan duina baldin bada (8. helburua), nola komunikatu eraginkortasunez lantokian?; nola gutxitu ezberdintasunak hizkuntza gutxituen hiztunek ez badituzte beren kultura eta ezagutza garatzeko aukera berak? (10. helburua: herrialde bakoitzean eta herrialdeen artean desberdintasunak murriztea); nola babestu giza eskubideak hiztunen eskubideak kontuan hartzen ez badira? (16. helburua: garapen jasangarrirako gizarte baketsuak eta inklusiboak sustatzea, guztioi justiziarako sarbidea erraztea, eta erakunde eraginkorrak eta inklusiboak sortzea maila guztietan). Informazioa modu egokian zabaltzea garrantzizkoa baldin bada, are gehiago izango da hiztun guztiengana iristeko moduko hizkuntzak erabiltzea.

Gizataldeen pobrezia eta bazterkeria, eta askotan horri lotzen zaizkion bortxaketa eta biolentzia gizatalde horien identitate-, kultura- eta hizkuntza-ezaugarriak baztertzearekin lotuta egon ohi dira [2,3]; aldiz, giza izaeraren ezaugarri horiek kontuan hartuta egiten den garapen-ahaleginak askoz emaitza hobeak ekartzen ditu haien bizi-kalitatea hobetzeko.

Arrazoi horietan oinarrituta, 2017. urtean, Euskal Herriko Unibertsitateko (UPV/EHU) Munduko Hizkuntza Ondarearen UNESCO Katedrak (MHOUK), Donostiako Easo Politeknikoarekin batera, gogoetarako eta zabalkunderako ekimen bat abiarazi zuen, «17+1» izenarekin. 2030 Agendaren 17 helburuei beste bat gehitzea proposatu zen, 18. helburu bat (3. irudia); alegia, «kultura- eta hizkuntza-aniztasunaren bermea» aldarrikatzen duena.
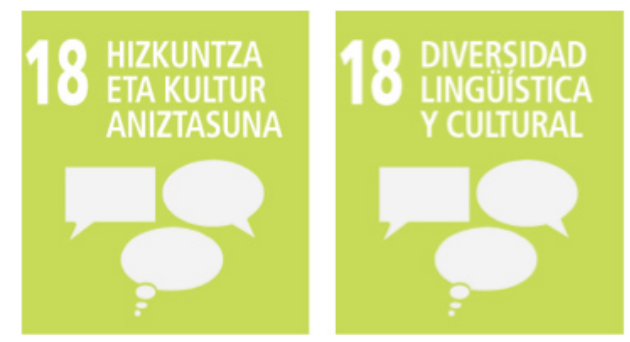

3. irudia. 18. helburua (Iturria: MHOUK).

Beraz, hizkuntzen helburuak beste helburu guztiekin lotura duela ikusirik, eskuartean dugun lan honen xedea zera da: aldarrikatzen dugun 18. helburu horrek 2030 Agendako 17 GIHetan zer eragin duen aztertzea. Izan dezakeen edo izan behar lukeen inpaktua erakutsi nahi genuke. Horretarako, helburuen artean bat aukeratu, eta hartan zentratuko gara. Gure lan-arloa eta -esperientzia bereziki hezkuntza eleaniztunari lotua izanik, 4. helburuari begira jarriko gara, kalitatezko hezkuntza inklusiboa bermatzea goiburu 
hartzen duenari. Ondo frogatua dago hezkuntza-alorreko garapen iraunkorrerako erronketan garrantzitsuena dela hizkuntza gutxitua kontuan hartzen duen hezkuntza eleaniztuna bideratzeko erronka, baita gizatalde txiro eta baztertuentzat ere [7]. Helburu horri hizkuntza-aniztasunaren ikuspegitik gainbegirada eman ondoren, «17+1» aldarrikapenean jarriko dugu arreta, eta balizko 18. helburuaren eta hura erdiesteko kontuan har litezkeen jomugen formulazioari ekingo diogu.

\section{KALITATEZKO HEZKUNTZA (4. HELBURUA) ADIBIDE GISA. ZER LOTURA DU HIZKUNTZEKIN?}

Hizkuntzaren eta hezkuntzaren arteko harremana banaezina da. Dagoeneko esan dugun bezala, hezkuntza funtsezkoa da gizartearen garapenerako. Hala eta guztiz ere, munduan 6.000 hizkuntzatik gora dauden arren, \% 33k bakarrik dute presentzia hezkuntzan [8]. Horrek esan nahi du badirela hiztun asko ezin direnak alfabetatuak izan beren komunitateko hizkuntzan. Askotariko arrazoiak daude horretarako. Zenbaitetan, hiztun kopuru txikia eta hizkuntzaren bizkortasun eza daude oinarrian, baina, sarritan, eta hori da munduko hizkuntza askoren kasua, kolonialismoaren eraginez jasan duten gutxiespena da arrazoia. Beste batzuetan, hiztun asko izan eta hizkuntza biziak diren arren, ez dute gauzatu oraindik estandarizazio-prozesurik, eta horrek zaildu egiten du hiztunen alfabetatzea, eskolatzea eta, ondorioz, lanerako sarbidea eta garapen profesionala.

Garapen Iraunkorrerako 2030 Agendan, honela formulatzen da 4. helburua: «Guztiontzako kalitatezko hezkuntza inklusiboa nahiz bidezkoa bermatzea eta etengabeko ikaskuntzarako aukerak bultzatzea» [6]. Aldi berean, ekimen-marko bat ezarri, eta Incheon-eko Adierazpena argitaratu zen [9], helburua garatzeko tresna lagungarria izateko asmoarekin. Adierazpen horretan, aipamen esplizitua egiten zaio eleaniztasunari:

Testuinguru eleaniztunetan, ahal den guztietan eta nazioen eta azpinazioen errealitate, gaitasun eta politikak kontuan hartuta, lehen hizkuntzan edo etxean hitz egiten den hizkuntzan ikastea eta irakastea sustatu beharko da. Mundu osoan interdependentzia soziala, ingurumenekoa eta ekonomikoa areagotu dela kontuan hartuta, atzerriko hizkuntza bat gutxienez ikasgai gisa eskaintzea ere gomendatzen da. [9]

Baita helburua lortzeko estrategiari buruz hitz egiten duenean ere:

Testuinguru eleaniztunetan, hezkuntza elebiduna eta eleaniztuna sustatzea, haurren lehen hizkuntzan edo etxean hitz egiten den hizkuntzan goiz irakasten hasita. [9] 
Eta proposatzen diren adierazleez hitz egitean:

Etxean hitz egiten duten hizkuntza - edo lehen hizkuntza - ikasketen hizkuntza duten ikasleen ehunekoa Lehen Hezkuntzan. [9]

Gakoa, ordea, eleaniztasunak eskolan duen trataeran dago, ez bakarrik kopuruan. Nola kudeatzen da eleanizasun hori? Zenbateraino eta zertarako hartzen dira aintzat hizkuntza indigena edo autoktonoak? Nolako prestakuntza dute tokian tokiko hizkuntzetan irakatsiko duten irakasle elebidunek?

Nazio Batuen GIHen 2019ko jarraipen-txostenak [10] datu etsigarriak erakusten dizkigu: 617 milioi ume eta gaztetxok ez zuten lortu ez irakurtzeko ez matematikarako gutxieneko gaitasunik; munduan, 750 milioi heldu analfabetoak dira, eta haien artetik bi heren emakumeak dira; 6-17 urte bitarteko ume eta gaztetxoen artean, 5etik 1 ez da joaten eskolara, gehiago emakumeen kasuan, eta abar. Horri guztiari 2020. urtean COVID-19ak eragindako pandemiaren ondorioak gehitu behar zaizkio. Munduko 190 lurraldetan itxi dituzte eskolak, eta munduko ikasleen \% 90 eskolatik kanpo geratu da. Arazoari aurre egiteko leku askotan urrutiko hezkuntza eta Internet bidezkoa martxan jarri den arren, 500 miloi ikaslek ez dute izan horretarako aukerarik [11]. Kalitatezko haur -hezkuntza funtsezkotzat hartzen da eskolatze-prozesua osatzeko orduan, baina lurraldeen arteko ezberdintasunak oso handiak dira oraindik, askotan azpiegitura egokiak eta era guztietako baliabideak falta direlako. Agerian geratu da hori, adibidez, 2020ko pandemia-garaian, munduko Lehen Hezkuntzako eskola guztien $\%$ 65ek besterik ez baitute oinarrizko instalaziorik eskuak garbitzeko; \% 38k, Afrikaren kasuan. Are gehiago, 379 milioi ume eskolako otordurik gabe geratu ziren eskolak itxi zirelako [11].

Baina, azpiegiturez haratago, badakigu eskola-porrotaren eta eskola behar baino lehenago uztearen arrazoi nagusietako bat beste bat dela, hots, hizkuntza hegemonikoaren erabilera eta tokiko beste hizkuntzak eskolatik at uztea. Hona hemen, esate baterako, datu batzuk (4. irudia).

Hizkuntza hegemonikoaren erabilera, gainera, hiztunentzat arrotzak diren munduko ezagutzetan oinarritzen da, kontuan hartu gabe bertako hizkuntzak garraiatzen duen berezko ezagutza. Ondorioz, hizkuntza hegemonikoaren bidez ezagutza-eredu deskontestualizatuak ezartzen dira [13], komunitateen kosmobisiotik urruti daudenak, eta komunitatearen hizkuntza- eta kultura-eskubideak alboratu egiten dira. Egun bizi garen mundura egokitzeak, ordea, ez du esan nahi uko egin behar zaionik hizkuntza- eta kultura-ondareari edo baztertu egin behar direnik oinordetzan jasotako ezagutzak; hizkuntza-lankidetzaren alorrean egindako lan baten harira [14] gogorarazten den bezala, hizkuntza, kultura eta identita- 
tea gakoak dira garapen orekatu, duina eta justua lortzeko. Horregatik da garrantzizkoa tokian tokiko hizkuntzak hezkuntzan egotea. Are gehiago, badira herri indigenak hizkuntzaren eta lurraren babesa elkarri lotuta ulertzen dutenak, eta hori garrantzizkoa da garapen iraunkorra ikusmiran baldin badugu.

Gráfico 1: Cuando el Idioma en el hogar y en la escuela difieren, se evidencla un efecto negativo en las calificaciones obtenidas

Porcentaje de nlî́os partıclpantes en una evaluación que alcanzaron el nivel mínımo internacional de referencla en materla de lectura.

a. Habla la lengua en el hogar, África Occidental

Togo, PASEC, 2010

Benín, PASEC, 2005

Côte d'Ivoire, PASEC, 2008

Burkina Faso, PASEC, 2007

Senegal, PASEC, 2007

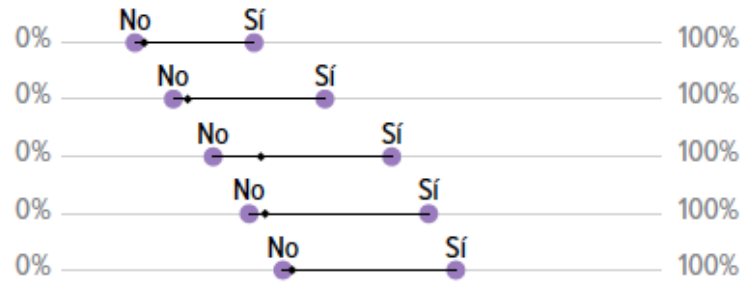

b. Habla la lengua en el hogar, Irán, R. I. de

Primaria, PIRLS, 2011

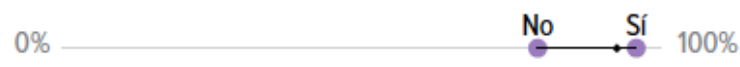

c. Habla la lengua en el hogar, Honduras

Primaria, PIRLS, 2011

$0 \%$

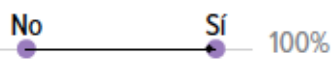

Fuente: Base de Datos Mundlal sobre la Desigualdad en la Educación (WDE).

4. irudia. Hizkuntzen eragina hezkuntza-emaitzetan [12].

Mendebaldeko Afrikako lurralde askotan, adibidez, hizkuntza gutxituek bizkortasun handia duten arren eguneroko harremanetan, oraindik ere frantsesa da irakaskuntza-hizkuntza; ondorioz, hizkuntza gutxituko hiztunen artetik \% 25ek lortzen dute eskolako hizkuntzan irakurtzeko gaitasuna. Guatemalan, bestalde, eskola eleaniztunetan (alegia, bertako hizkuntza eta hizkuntza hegemonikoa erabiltzen dutenetan) ikasten duten ikasleak sarriago joaten dira eskolara eta gutxiagotan uzten dute eskolatzea behar baino lehenago. UNESCOren txosten horretan [12], beste gomendio zehatz batzuen artean garbi adierazten da, bestalde, hezkuntza elebidun edo eleaniztuneko programak sustatu behar direla ama-hizkuntzatik hezkuntzako 
hizkuntza ofizialerako trantsizioa egiteko. Halaber, tokian tokiko hizkuntzan irakasteko gaitasuna izango duten irakasleak prestatzearen garrantzia azpimarratzen da.

Mezu eta gomendio horiek, ordea, gehienetan antzuak dirudite. Munduko hezkuntzaren egoera aztertzen duen 2020ko txostenean [15], arreta berezia eskaintzen zaie ume, gazte eta helduen diskriminazioa eragiten duten eta ondorioz pertsona horiek hezkuntza-sistematik at uzten dituzten mekanismo sozial, ekonomiko eta kulturalei. Eskola inklusiboarekin lotutako alderdiak dira, eta hezkuntzak aintzat hartu behar dituenak, baina, aldi berean, txostenak dio inklusioaren mesedetan hainbat talderen identitate, praktika, hizkuntza eta sinesmenak gutxietsita gera daitezkeela.

Hezkuntza eleaniztunari gagozkiolarik, munduan zehar ama-hizkuntzan oinarritutako esperientzia ugari dago, nahiz eta oso helburu eta eraginkortasun ezberdinak dituzten [16]. Bereziki hizkuntza gutxituen kasuan, badirudi ezinbesteko baldintza dela ama-hizkuntzan edo tokiko hizkuntzan eskolatzea, haiek garatu eta prestigioa izan dezaten. Horrek ez du esan nahi, ordea, hizkuntza gutxitua izan behar denik eskolako hizkuntza bakarra. Hiztun horientzat, gaur egun ezinbestekoa da beste hizkuntza batzuk ere ikastea; tartean, jakina, hizkuntza hegemonikoa, diskriminaziorik paira ez dezaten. Hortaz, hezkuntza eleaniztuna da aukerarik egokiena hizkuntza gutxituetako hiztunentzat, eta, ahal dela, hizkuntza gutxitu horrek izan behar luke ardatza; izan ere, gutxitua izanik, eskolaren babesari eta sustapenari esker garatu daiteke. Hizkuntza gutxituan oinarritzen diren hezkuntza-eredu eleaniztunak, beren zailtasun guztiekin, posible dira, eta, Euskal Herrian frogatu den bezala, eraginkorrak dira, ez soilik bertako hizkuntza gutxituarentzat, baizik eta baita hegemonikoarentzat ere [17, 18, 19]. Oso testuinguru ezberdinetan egindako esperientziek ere [20] erakusten dute bide hori egokia dela; esate baterako, Senegalen, non wolofera eta pulaarra hizkuntza gutxituak diren eta frantsesa hegemonikoa, edo Kanbodian, non hizkuntza nagusiarekin batera (khmerera) beste bost hizkuntza gutxitu erabiltzen diren (brao, bunong, kavet, kreung eta tampuen). Hala eta guztiz ere, hori ez da esperientzia hedatuena. Afrikako zenbait lekutan, kasurako, tokian tokiko hizkuntzen erabilera ahozko komunikaziora mugatzen da; hango testuinguru eleaniztuna kontuan harturik, eta aintzat hartuta eskolan hasten diren ume gehienek ez dutela ezagutzen eskolako hizkuntza gehienetan hegemonikoa eta/edo koloniala erabiltzen delako, ondorioa da ikasleek oso eskolatze-maila eskasa lortzen dutela; eskolak ez du aintzat hartzen ezta baloratzen ere bertako hizkuntzan duten ahozko ezagutza, eta, hizkuntza hegemonikoaren ezagutza txikia tarteko, ez dute lortzen irakurketa-idazketa prozesua menderatzea [21]; hori oztopo handia da alfabetizazio eraginkorra lortzeko. Munduan zehar, badira Kulturarteko Hezkuntza Elebiduna (gaztelaniaz, Educación Intercultural Bilingüe) sustatzen dituz- 
ten programak, bereziki Latinoamerikan, baina, oro har, ez dira oso eraginkorrak izan hizkuntza indigenen edo autoktonoen biziberritzerako, ezta hiztunen alfabetizaziorako ere [22].

Ikuspegi ekonomikotik, eskola eleaniztunak, gainera, ez du zertan izan eskola elebakarra baino garestiagoa. Sarritan sortzen den zalantza da amahizkuntzan oinarritutako hezkuntza ekonomikoki bideragarria ote den eta lehentasuna izan behar ote den. Afrikari buruz adituek [13] dioten bezala, hizkuntza hegemoniko hutsa erabiltzen duen eskola elebakarra ez da eraginkorra, eta egundoko giza baliabideak eta baliabide ekonomikoak behar ditu. Ildo horretatik, nabarmentzen duten bezala [21], eskola eleaniztuna elebakarra baino efizienteagoa izan daiteke, errendimendu handiagoa duelako; azken batean, hizkuntza hegemonikoan bideratzen den hezkuntzan, ikasleek denbora gehiago behar dute eskolatuak izateko, gehiago errepikatzen dute maila bera eta, horrenbestez, denbora gehiago igarotzen dute eskolan; eskola eleaniztuna, ordea, ikasmailen errepikapena eta eskola-porrota saihesteko bidea izan daiteke, eta, horrenbestez, baliabide gutxiago behar ditu; are gehiago, zenbat eta denbora luzeagoan ikasi hezkuntza-sistema eleaniztun batean, gero eta emaitza hobeak lortzen dira, hobeto formatutako langileak lortzen dira, eta itzulkin ekonomikoa handiagoa da. Azken batean, balio ekonomikoa ez datza soilik eskolak bere jarduera gauzatzeko behar duen aurrekontuan; epe ertainera eta luzera dituen onurak ere aintzat hartu behar dira. Bestelako onuren artean, gainera, honelakoak ere aipatzen dituzte adituek [21]: populazioa aktibatzen du, zabalkundean laguntzen du, komunikazio-oztopoak suntsitu eta gatazkak konpontzen laguntzen du. Munduko Hizkuntza Ondarearen UNESCO Katedran izandako esperientzian, horren adibide dira Kolonbiako Cauca Departamentuan hizkuntza-lankidetzaren bidez eragindako aldaketak [23], non, komunitateak berak eskatuta eta inplikatuta, nasa yuwez ikasteko eskolak sortu diren.

Oro har, hizkuntza garapen-eragile izan daiteke. Sarreran aipatu ditugu UNESCO Bangkok [3] txostenean hizkuntzaren garapen-indarra adierazteko agertzen diren argudioak. Baztarrikak [1] euskararen adibidea dakarkigu, eta bertan erakusten du hizkuntza gutxituaren aldeko politika garapen iraunkorrarekin (giza garapena eta ekonomia-garapena) bateragarria izan daitekeela edota bi alderdiek elkar indartu dezaketela. Artikuluan, dokumentazio zehatzaren bidez ondo argudiatzen da alderaketa hori. Lotura horren ziurtapen gisa, Euskal Autonomia Erkidegoan (EAE) 1980tik 2017ra bitartean egon den bilakaera erakusten du. Garapen soziolinguistikoa (euskal hiztunen bilakaera, esate baterako: 1981ean, \% 21 ziren euskaldunak; 2016an, \% 41) eta aldi berean gertatzen den garapen ekonomiko eta soziala (adibidetarako: 1980ko langabezia \% 25 ingurukoa zen, eta 2017koa, $\%$ 11,6koa) datu ugarirekin erakusten da gutxienez bateragarriak direla. Hizkuntza gutxitu baten erabilerak giza garapenean eragin zehatza duela 
erakusten duten adibide konkretuak ere bila daitezke. Aurten bizi dugun pandemia-egoera dela-eta Baztarrikari berari entzun diogu Gipuzkoako herri-aldizkariak eta bestelako hedabide euskaldunak (Hitza, Goiena...) oso baliagarriak izan direla herriz herri informazio zehatza eta eraginkorra emateko. Horrek adierazten du euskararen erabilerak komunikazioaren kalitatea hobetu duela. Beste adibide garbi bat hezkuntzan ikus daiteke: euskara izan da EAEn eskola elebidunak lehenengo eta eleaniztunak geroago sorrarazi dituen arrazoi nagusia; sistema elebiduna martxan jarri zenean, sakonki ebaluatu zen, eta emaitzak eskola elebakarretakoak baino hobeak zirela frogatu.

\section{HAMAZAZPI HELBURU GEHI BAT $(\ll 17+1 »)=18$. HELBURUA: HIZKUNTZA- ETA KULTURA-ANIZTASUNAREN BERMEA}

Nazio Batuen Batzar Nagusian onartutako 2030 Agenda garapen iraunkorra lortzeko ekintza-plan unibertsala bilakatu da. Halere, esan bezala, Agendak alde batera uzten du hizkuntzen alorra, eta oso gutxi hartu du kontuan kultura garapen iraunkorrerako funtsezko elementu gisa. Doktrinek eta esperientziek [2,3], Euskal Herriari dagokionez [1], behin eta berriro erakutsi dute hizkuntzak ekonomiaren motorra direla, giza kohesioaren eta bakearen bultzatzaileak eta, azken batean, giza eskubide kontu bat; horregatik, garapen iraunkorrak nahi eta nahi ez hartu behar ditu kontuan. Munduko leku pobreenak eta desberdintasun handienak dituztenak dira, hain zuzen, kultura- eta hizkuntza-aniztasun gehien duten guneak, baita aldaketa klimatikoaren eraginak gehien jasaten dituztenak ere [3]. Halaber, gune horietan, sarri, esplotazio multinazionalean oinarritutako garapen-ereduak jasan behar izaten dituzte, eta horrek baztertze eta indarkeria handia sorrarazten du, batez ere emakumeen kontra. Horrez gain, komunitateek mendeetan zehar garatutako jakintzak, besteekin eta ingurumenarekin elkar ulertzeko erabilitakoak, betiko galtzen ari dira. Agendak adierazten duen moduan, pobrezia bada mundu-mailan daukagun arazorik larriena, ezingo diogu aurre egin modu egokian lekuan lekuko kultura- eta hizkuntza-berezitasunak kontuan hartzen ez baditugu. Horregatik, nork bere hizkuntzari ematen dion garrantzia aitortzea ezinbestekoa da pobrezia eta gosea eragozteko.

Hori guztia agerian geratu da Nazio Batuek hizkuntzari, garapen iraunkorrerako helburuei eta populazio zaurgarriari buruz egindako sinposioetan. 2016ko bilkuraren ondoko txostenean [24], adituek azpimarratu dute garrantzizkoa dela garapen iraunkorrerako helburuen marko osoa berrikustea haien planifikazioan eta inplementazioan hizkuntza ezinbesteko faktore den eremuetan: «Premia larria dago hizkuntza sartzeko GIHetako bakoitzaren planifikazio-, gauzatze- eta ebaluazio-faseetan» [24]. Izan ere, GIHen inguruko maila goreneko eztabaidetan, oro 
har, ingelesa erabiltzen da lingua franca gisa, baina horrek, onurak baino gehiago, desabantailak izan ditzake. Hona hemen txosten horretan bertan egiten diren gogoeta batzuk:

Zenbait hizkuntza menderatzeak, bereziki ingelesa, ahalegin global bateratu baten ilusioa sortzen du nazioarteko garapenaren diskurtsoan. Izan ere, domeinu horrek zabaldu egin du politikak ikertu, eztabaidatu eta idazten dituzten elite anglofonoen eta politika horiek maila indibidualean inplementatu behar dituzten milaka milioien arteko amildegia, eliteek berek oharkabean pasa ditzaketen frustrazio-mailak sortuz, hain zuzen ere, beren eztabaidak garatzen diren ingurune elebakarraren eraginez. Horrela, elkarrizketak norabide bakarrera jo ohi du: planifikatzaileengandik planifikatutakora. Askotan, planifikatzaileen eta pertsonen arteko elkarrekikotasun- eta berdintasun-giroko elkarrizketa eragozten du hizkuntzak. [24]

Norberarena ez den hizkuntza bat erabiltzeak desabantailan jartzen du norbera, eta hierarkia-zentzua sortzen du, eta horrek ideien bidezko trukea oztopa dezake, adostasunera iristeko ahaleginak arriskuan jar ditzake, eta helburu komuna ahultzen duen erresumina sor dezake (ingelesezko hiztunek, bereziki, sarritan ez dituzte efektu horiek nabaritzen, eta ez dira haietaz ohartzen). Eta helburuak betetzeko konpromisoa dutenentzat ulergarria den hizkuntzarik ez izatea, adibidez, adostasunetik kanpo geratzea da. [24]

Ingelesaren erabilera, beraz, gure hizkuntzekiko ezjakintasunaren erakusleiho ere izan daiteke, eta, gauzak bideratzen lagundu beharrean, gaizki-ulertuen eta mesfidantzaren iturri izan daiteke, baina batez ere diskriminazioaren eragile:

Hizkuntza indigenen gutxiengoen edo ondare gutxiengoen kasuan, bereziki prestigio txikia duten hizkuntzetako hiztunen kasuan, desberdintasuna areagotu egiten da diskriminazio juridikoa, ekonomikoa, hezkuntzazkoa eta soziala instituzionalizatuta, hezkuntza-hizkuntza eta gobernuhizkuntza eskuraezin gisa. [25]

Eleaniztasuna, garapenaren komunitatean, askotan bigarren mailan gertatzen den itzulpen-prozesutzat hartzen da. Inplizituki onartzen da hizkuntza-kanal egokiak erabiliko direla informazio zuzena eta esanguratsua populazio hartzaileei zabaltzeko, baina arreta kontziente gutxi jartzen da norabide biko hizkuntza-komunikazioaren hobekuntzan, gaizki-ulertuak edo komunikazio-akatsak saihesteko erabakiak hartzeko prozesuan. [25]

Ikusten dugun bezala, aniztasunaren garrantzia ez da oharkabean igarotzen hizkuntzen betaurrekoak jartzen ditugunean. Gaiari buruz urtero egi- 
ten diren bilkuretan, behin eta berriz geratzen da agerian hizkuntzak garapen iraunkorrerako helburuetatik at uzteak dakarren gabezia.

\subsection{Zer xede proposa litezke 18. $(« 17+1 »)$ helbururako?}

Kontuan hartuta, beraz, hizkuntzen garrantzia, zein izango lirateke lehentasunak balizko 18. helburua ( $« 17+1 »)$ erdieste aldera? Esaten ari garen bezala, Nazio Batuen 2030 Agendan [6] ez da formulazio espliziturik egiten hizkuntza-aniztasunarekin lotutako helburu bat formulatzeko. Horregatik, «17+1» gogoetatik abiatuta formulatu dugu 18. helburu orokorra (5. irudia).

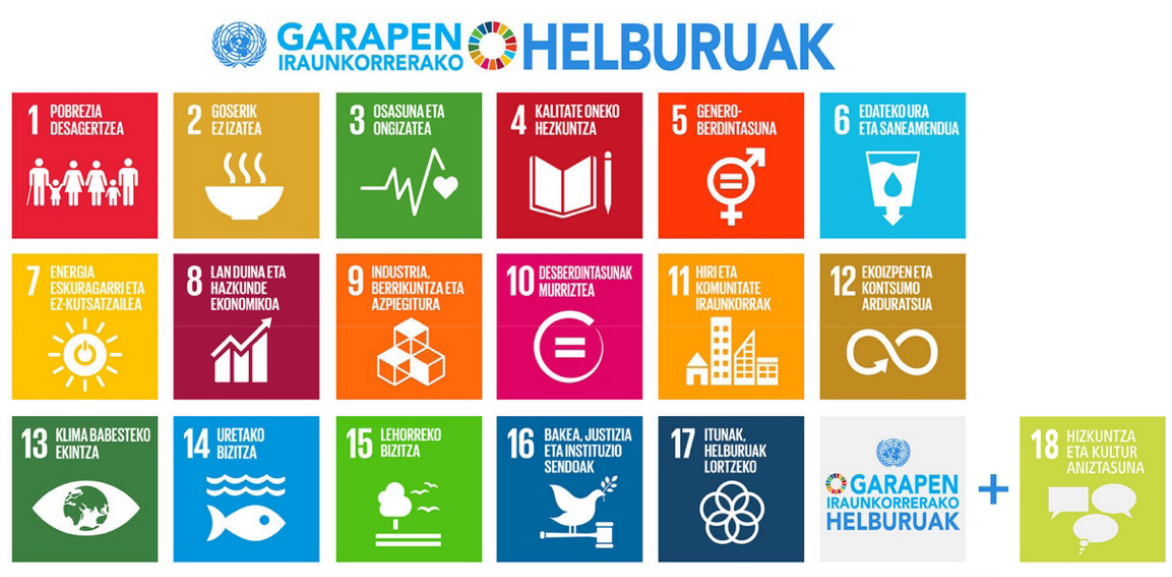

5. irudia. GIHen panela MHOUKren «17+1» proposamenari egokituta.

Halaber, hutsune hori betetze aldera, helburu horretara iristeko jomugen formulazio zehatzagoa egingo dugu datozen lerroetan, betiere Euskal Herrian dugun hizkuntza gutxituaren (euskara) biziberritzean izandako esperientziatik abiatuta, gorago azaldutakoa kontuan hartuta, eta bereziki hizkuntza-lankidetzan aplikatzeko eskaintzen diren oinarriak [5] edo ekintza-ildoak aintzat hartuta. Hona, beraz, hizkuntza-aniztasunaren helburua irudikatzeko modu bat.

Ikusten dugun bezala, formulazio horretan ageri diren jomugek lotura estua dute giza garapenarekin, baita beste helburu garrantzizko batzuekin ere: besteak beste, justizia, hezkuntza eta osasuna. 
1. taula. Hizkuntzen helburua GIHetan irudikatzeko modu bat.

18. HELBURUA: Hizkuntza eta kultura guztien presentzia eta aintzatespena bermatzea pertsonen eta gizarteen garapenerako.

18.1. Hizkuntza gutxituak dituzten komunitateak ahalduntzea eta ezagutaraztea, identitateak indartzeko.

18.2. Herri eta kultura askotarikoak kontuan hartzen dituzten lege egokiak eta hizkuntza-politika eraginkorrak bultzatzea.

18.3. Tokian tokiko hizkuntzen integrazioa lortzea hezkuntza-sistemetan, gutxienez Lehen eta Bigarren Hezkuntzan.

18.4. Gutxienez hizkuntzen erabilera praktikoa bermatuko duten hezkuntza-eredu eleaniztunak bultzatzea, betiere hizkuntza gutxitua modu eraginkorrean irakasten dela eta atzerriko hizkuntza bat ere ikasten dela ziurtatuta.

18.4.1. Tokian tokiko hizkuntzetan irakatsiko duten irakasle eleaniztunen prestakuntza bideratzea hiztunen alfabetizazioa eta prestakuntza akademikoa bermatzeko.

18.5. Eten digitala murriztea eta teknologia berriak hizkuntza guztietan eskuragarri jartzea, batez ere hizkuntza gutxituetan.

18.6. Hizkuntza gutxituen presentzia bermatzea hedabide mota guztietan: idatzizkoak, ikus-entzunezkoak edota teknologia berrien alorrean garatutakoak.

18.7. Zerbitzu publikoetan, batez ere osasunaren eta justiziaren alorrean, komunitate guztien hizkuntzen erabilera bultzatzea, bereziki komunitate indigenen kasuan.

18.8. Hirugarren herrialdeetako programetan, hizkuntza-irizpidea kontuan hartzea proiektuetako fase guztietan: identifikazioa, diagnostikoa, diseinua, garapena eta ebaluazioa.

Iturria: MHOUK.

\section{ONDORIOAK}

Bistan da hizkuntza-aniztasuna eta hizkuntza autoktonoak aintzat hartzea premiazkoa dela benetako garapen iraunkorra eta justua lortzeko. Azken batean, hizkuntza funtsezko tresna da mundu guztira eta pertsona guztiengana iristeko, GIHen mezua behar bezala zabaltzeko eta 2030 Agendak bere bidea egin dezan. 
2030 Agendan, kultura, tolerantzia, elkarrenganako errespetua eta munduko herritarren balio etnikoen eta erantzukizun partekatuaren arteko ulermena sustatzeko konpromisoa aipatzen da [6], eta gizabanakoa jarri nahi da GIHen erdigunean. Gizabanako hori, baina, hizkuntza jakin bateko hiztuna da, eta, horrenbestez, pertsona oinarrian izateak hiztuna oinarrian izatea esan nahi du. Hiztunak giza eskubide batzuk ditu, eta, haren hizkuntza aintzat hartzen ez bada, haren eskubideei erasotzen zaie. Hizkuntzekiko errespetuak ekitate-printzipio bat izan behar du.

Hartu beharreko bidea zein den azpimarratzen duen adierazpen batekin amaituko dugu:

Badirudi Nazio Batuek eta interesdun guztiek berehalako arreta eskaini behar diotela hizkuntza-justiziari, GIHak benetan ahalegin pluralista eta osotua bihurtzeko beharrezkoak diren alderdi praktikoen ikuspegi patxadatsu eta neurrikoa izatearekin batera. [24]

Euskal Herrian daukagun eskarmentua kontuan izanda, nabaria da komunitateen garapenean hizkuntzek eta kulturek duten garrantzia. Horregatik, egindako ibilbidea gizarte osora zabaltzeko ardura hartu behar dugu, kulturaren, hizkuntzaren eta gizakiaren arteko lotura agerian jartzeko, eta elementu horiek komunitatearen garapen integralean duten rola nabarmentzeko. GIH guztien garapenean ikuspegi eleaniztuna txertatzea eta inplikatuta dauden arlo guztietan hizkuntzari lotutako jomuga bat (eta, jakina, hura neurtzeko adierazleak) ezartzea edo, gutxienez, gogoeta hori aurrean izatea bide eraginkorra izan daiteke hizkuntzen eragina aintzat hartzeko.

\section{ESKER ONA}

Artikulu hau gure proiektua dirulaguntza batekin babestu duten erakunde hauei esker egin da: Eusko Jaurlaritzako Kultura eta Hizkuntza Politikarako saila, Azkue Fundazioa, Elorrioko Udala, Berrizko Udala eta Eusko Jaurlaritzaren ikerketa-sareko IT983-16 talde kontsolidaturako dirulaguntza. Eskerrak, baita ere, Donostiako Easo Politeknikoari, «17+1» ekimenean egindako ekarpenagatik.

\section{OHARRA}

Autoreak dira hemen agertzen diren informazioak aukeratu eta aurkeztearen erantzule, bai eta haietan adierazitako iritzien erantzule ere; iritzi horiek ez dira nahitaez UNESCOrenak, eta ez dute erakunde hori konprometitzen. 


\section{BIBLIOGRAFIA}

[1] BAZTARRIKA, P. 2019. «El modelo vasco de revitalización lingüística y desarrollo sostenible». In I. Idiazabal eta M. Pérez-Caurel (arg.). Linguistic diversity, minority languages and sustainable development. UPV/EHUko Argitalpen Zerbitzua, Bilbo. 239-262. [https://web-argitalpena.adm.ehu.es/ pasapdfFin.asp] (Eskuratuta: 2020ko irailean).

[2] ROMAINE, S. 2019. «Linguistic diversity, sustainability and multilingualism: global language justice inside the doughnut hole». In I. Idiazabal eta M. Pérez-Caurel (arg.). Linguistic diversity, minority languages and sustainable development. UPV/EHUko Argitalpen Zerbitzua, Bilbo. 40-61. [https://web-argitalpena.adm.ehu.es/pasapdfFin.asp] (Eskuratuta: 2020ko irailean).

[3] UNESCO. 2012. Why Language Matters for the Millennium Development Goals. UNESCO, Bangkok. [https://unesdoc.unesco.org/ark:/48223/ pf0000215296] (Eskuratuta: 2020ko irailean).

[4] NAZIO BATUAK. 2000. Declaración del Milenio. [https://www.un.org/ spanish/milenio/ares552s.htm] (Eskuratuta: 2020ko irailean).

[5] URANGA, B. 2013. Garapenerako lankidetza-proiektuetan hizkuntza-irizpidea txertatzeko proposamena. UNESCO Etxea, Bilbo.

[6] UNESCO ETXEA. 2015. Gure Mundua Eraldatzea. 2030, Garapen Jasangarrirako. Bilbo-UNESCO Etxea. [Jatorrizko bertsioa: Transforming our World: The 2030 Agenda for Sustainable Development, Nazio Batuen Erakundeak 2015ean ingelesez argitaratua] [http://www.unescoetxea. org/dokumentuak/2030_Agenda_garapen_jasangarrirako.pdf] (Eskuratuta: 2020ko irailean).

[7] IDIAZABAL, I. eta PÉREZ-CAUREL, M. (arg.). 2019. Linguistic diversity, minority languages and sustainable development. UPV/EHUko Argitalpen Zerbitzua, Bilbo. [https://web-argitalpena.adm.ehu.es/pasapdfFin.asp] (Eskuratuta: 2020ko irailean).

[8] MARTÍ, F.; ORTEGA, P.; IDIAZABAL, I.; BARREÑA, A.; JUARISTI, P.; JUNYENT, C.; URANGA, B. eta AMORRORTU, E. (arg.). 2006. Palabras y mundos. Informe sobre las lenguas del mundo. Bartzelona: Icaria.

[9] UNITED NATIONS EDUCATIONAL SCIENTIFIC AND CULTURAL ORGANISATION [UNESCO]. 2016. Declaración de Incheon y Marco de Acción ODS 4 - Educación 2030. [https://unesdoc.unesco.org/ark:/48223/ pf0000245656_spa] (Eskuratuta: 2020ko irailean).

[10] NAZIO BATUAK. 2019. Informe de los Objetivos de Desarrollo Sostenible 2019. New York [https://reliefweb.int/report/world/informe-de-los-objetivos-de-desarrollo-sostenible-2019] (Eskuratuta: 2020ko irailean).

[11] NAZIO BATUAK. 2020. The Sustainable Development Goals Report 2020. [https://unstats.un.org/sdgs/report/2020/] (Eskuratuta: 2021eko irailean). 
[12] UNESCO. 2016. Informe de seguimiento de la Educación en el Mundo. Si no entiendes como puedes aprender? [https://unesdoc.unesco.org/ark:/48223/ pf0000243713_spa] (Eskuratuta: 2020ko irailean).

[13] WOLFF, H.-E. 2019. «Plurality and diversity of kanguages in Africa: asset for sustainable development?». In Idiazabal eta M. Pérez-Caurel (koord.). Linguistic diversity, minority languages and sustainable development. UPV/ EHUko Argitalpen Zerbitzua, Bilbo. 74-98. [https://web-argitalpena.adm. ehu.es/pasapdfFin.asp] (Eskuratuta: 2020ko irailean).

[14] LARRAÑAGA, J. eta BARREÑA, A. 2021. «Hizkuntza-lankidetza: oraina eta geroa». In L. Diaz de Gereñu, L., I.M. Garcia-Azkoaga eta I. Manterola: Euskara oinarri eta eleaniztasuna helburu. UPV/EHUko Argitalpen Zerbitzua, Bilbo. 273-286.

[15] UNESCO. 2020. Resumen del Informe de Seguimiento de la Educación en el Mundo 2020: Inclusión y educación: todos sin excepción. Paris, UNESCO. [https://www.schooleducationgateway.eu/es/pub/resources/ publications/-global-education-monitoring-.htm] (Eskuratuta: 2020ko irailean).

[16] CUMMINS, J. 2019. «Should schools undermine or sustain Multilingualism? An analysis of Theory, research, and pedagogical Practice». Sustainable Multilingualism, 15. 1-26. (DOI: https://doi.org/10.2478/sm-2019-0011).

[17] DIAZ DE GEREÑU, L. eta GARCIA-AZKOAGA, I.M. 2016. «Narraciones orales en vasco y español de niños inmigrantes: aprendiendo dos lenguas nuevas». Lengua y Migración / Language and Migration, 8, 1. zk., 29-49.

[18] GARCIA-AZKOAGA, I.M. eta IDIAZABAL, I. (arg.). 2015. Para una ingeniería didáctica de la educación plurilingüe. Euskal Herriko Unibertsitatea (UPV/EHU), Bilbo.

[19] ALDEKOA, A., MANTEROLA, I. eta IDIAZABAL, I. 2020. «A trilingual teaching sequence for oral presentation skills in Basque, Spanish and English». The Language Learning Journal, 259-271. (DOI: 10.1080/09571736.2020.1741666)

[20] BENSON, C. 2019. «The importance of learners'own languages in achieving Sustainable Development Goal Four (Ethiopia and Cambodia)». In Idiazabal eta M. Pérez-Caurel (koord.). Linguistic diversity, minority languages and sustainable development. UPV/EHUko Argitalpen Zerbitzua, Bilbo. 239-262. [https://web-argitalpena.adm.ehu.es/pasapdfFin.asp] (Eskuratuta: $2020 \mathrm{ko}$ irailean).

[21] OUANE, A. eta GLANZ, C. 2010. Why and how Africa should invest in African languages and multilingual education: an evidence- and practicebased policy advocacy brief. UNESCO Institute for Lifelong Learning. Hanburgo: Alemania. [http://www0.sun.ac.za/taalsentrum/assets/files/ML\%20 Afr\%20Lang\%20\&\%20Cost.pdf ] (Eskuratuta: 2020ko irailean).

[22] FLORES FARFAN, J.-A. 2019. «Las artes y los medios en los procesos de revitalización lingüística y cultural». In Idiazabal eta M. Pérez-Caurel (koord.). Linguistic diversity, minority languages and sustainable develop- 
ment. UPV/EHUko Argitalpen Zerbitzua, Bilbo. 162-180. [https://web-argitalpena.adm.ehu.es/pasapdfFin.asp] (Eskuratuta: 2021eko irailean).

[23] IDIAZABAL I. 2017. «QQué significa la escuela bilingüe para lenguas minorizadas como el nasa yuwe o el euskera?» [Monografía]. Onomázein: Las lenguas amerindias en Iberoamérica: retos para el siglo XXI, 138-152. (DOI: 10.7764/onomazein.amerindias.08).

[24] MARINOTTI, J.-P. (arg.). 2016. Language in UN. Final Report - Symposium on Language and the Sustainable Development Goals. (City University, New York, 21.22 April 2016). [https://sites.google.com/site/languageandtheun/events/2016-symposium-conclusions] (Eskuratuta: 2020ko irailean).

[25] MARINOTTI, J.-P. (arg.). 2017. Language in UN. Final Report - Symposium on Language, the Sustainable Development Goals, and Vulnerable Populations (City University, New York, 11-12 May 2017). [https://www. languageandtheun.org/symposium2017report.html] (Eskuratuta: 2020ko irailean). 